\title{
Hongmei Li, Advertising and Consumer Culture in
}

China,

Malden, MA, Cambridge, UK, Polity Press, 2016, 280 p.

\section{Ruoyun Bai}

\section{OpenEdition}

\section{Journals}

Electronic version

URL: http://journals.openedition.org/chinaperspectives/7425

DOI: $10.4000 /$ chinaperspectives.7425

ISSN: 1996-4617

\section{Publisher}

Centre d'étude français sur la Chine contemporaine

Printed version

Date of publication: 1 September 2017

Number of pages: $64-65$

ISSN: 2070-3449

\section{Electronic reference}

Ruoyun Bai, « Hongmei Li, Advertising and Consumer Culture in China, », China Perspectives [Online], 2017/3 | 2017, Online since 01 September 2017, connection on 23 September 2020. URL : http:// journals.openedition.org/chinaperspectives/7425; DOI : https://doi.org/10.4000/chinaperspectives. 7425

This text was automatically generated on 23 September 2020 .

(c) All rights reserved 


\section{Hongmei Li, Advertising and Consumer Culture in China,}

Malden, MA, Cambridge, UK, Polity Press, 2016, 280 p.

\section{Ruoyun Bai}

1 Advertising and Consumer Culture in China is an excellent survey of Chinese advertising as embedded in the context of marketisation, globalisation and authoritarianism in the market reform era. Approaching Chinese advertising "as an industry, a profession, and a discourse," Hongmei Li examines the formation and transformation of China's advertising industry from the late 1970s to the present, structural constraints upon the creative practices of its advertising professionals, and dominant discursive features of Chinese advertisements, all in response to "China's desire to emulate the Western development model while simultaneously incorporating Chinese culture, balancing

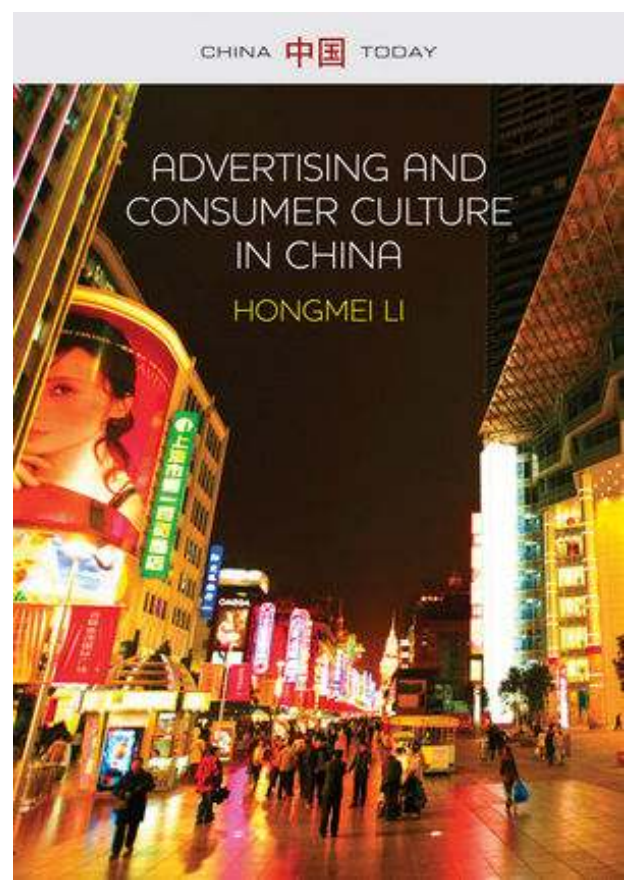
tensions between nationalism and cosmopolitanism, the local and the global, and tradition and modernity" (p. 16). The analytical focus is on Chinese advertising; multinational agencies and their ads are examined in various places mainly to contextualise, compare, and contrast. For readers interested in contemporary Chinese advertising, consumer culture, media, and China-West relations, this book provides an advanced, comprehensive overview. Cultural theorists, especially those of cultural 
globalisation, Orientalism, nationalism, and cosmopolitanism, will find Chinese advertising to be a highly intriguing area of inquiry.

The book is divided into seven chapters in addition to a succinct introduction and conclusion. Chapters 1 and 2 survey a number of theoretical concepts and historical events in Chinese advertising, which will be referenced in later chapters. Chapters 3 to 5 present a series of richly documented and carefully analysed case studies that illustrate how Chineseness is variously constructed by Chinese advertisers and their agencies caught between and creatively drawing upon nationalism and cosmopolitanism. The last two chapters shift to slightly different concerns, one on the evolving cultural and political boundaries of advertising as demonstrated by advertising controversies, and the other on the impact of digital technologies on advertising as manifested in the rise of branded entertainment and participatory marketing.

3 Chapter 3 examines "how neoliberal policies and the imagined West-China relations shaped advertising ideas and practices prior to China's entry into the WTO and during the subsequent grade period until 2005" (p. 5). It focuses first on a celebrity and maverick in Chinese advertising, Ye Maozhong, and then on a private advertising firm, Youbang, to illustrate the ways in which leading Chinese ad professionals capitalise on local knowledge while borrowing from Western practices. Specifically, local ad firms use Chineseness to create an advantage for themselves vis-à-vis multinational agencies. Thus, when promoting and prioritising local experiences, they may simply dismiss Western knowledge of advertising as inapplicable to China. Li notes that deploying the notion of Chineseness is not without pitfalls. By reifying the differences between China and the West, this business strategy runs the risk of unwittingly perpetuating the Orientalist discourse. The strategy becomes even more problematic when local ad firms tacitly endorse and practice labour exploitation, kickbacks, bribery, and corruption as "Chinese."

Chapter 4 continues to untangle the local-global dialectics by focusing on Chinese advertisers' strategies of selling products by appealing to nationalism, cosmopolitanism, or a blend of the two. Two to three ads are closely read and analysed to illustrate each strategy. Readers learn how legends, heroes, and symbols of China in the past and present are used to weave patriotism into meanings of advertised products ranging from an internet business to an herbal health drink and a hair product. They are also informed that while some Chinese commercials tap into national pride, others express a desire to associate their products with Western images, symbols, and values, reinforcing the idea of Western superiority through a contrived cosmopolitan outlook. A third category of Chinese ads represents a simultaneous articulation of nationalism and cosmopolitanism, celebrating universal humanity while making China the nation "a unifying factor" (p. 128). Drawing upon the argument that nationalism and cosmopolitanism are not mutually exclusive, Li suggests that the cosmopolitanpatriotic fusion can be seen as an ideological solution to the tension and anxiety caused by globalisation and an appeal to Chinese consumers' "desire for both Chineseness and global connections" (p. 132).

5 Chapter 5 is a case study of Li-Ning, a once prominent Chinese sportswear brand. Faced with the relentless expansion of Nike and other global sportswear brands in China, as well as stiff competition from domestic companies, Li-Ning has been going downhill despite desperate attempts to rebrand itself. The author employs De Kloet's notion of 
cosmopatriotism to describe Li-Ning's identity construction and negotiation in response to globalising forces. For example, on the one hand, it employs traditional and contemporary Chinese cultural elements in product designs; on the other hand, it signs NBA players to endorse its products. The hybrid identity, however, has not work well for Li-Ning. It has failed to impress foreign consumers, and it remained rustic-looking in the eyes of urban middle-class youths who prefer global brands, while having its consumer base in smaller cities and towns eroded by domestic competitors. Li observes that "even though Li-Ning is an iconic brand of national pride, it does not own national pride" (p. 154). National pride can easily be appropriated by top global sportswear brands if it means selling more to the Chinese. So McDonald's slogan goes "I'm loving it when China wins." Li identified a number of factors that might have led to the company's decline, ranging from excessive global expansion to a failed pricing strategy. There are things over which Li-Ning has very little control, such as the cultural capital that Western companies enjoy in the psychology of the Chinese. Li uses "cultural imperialism" to describe such effects. "Even though Chinese brands can produce a hybrid image of nationalism and cosmopolitanism, they are in a disadvantaged position because cultural imperialism privileges certain positions, naturalizes cultural distinctions, and creates competitive hurdles for Chinese products" (p. 161).

Chapter 6 discusses controversial advertising in China. In this chapter, Li examines laws, regulations, and government bodies that govern advertising content and practices, and explains how regulatory loopholes and unethical business and media practices, coupled with rapid and uneven changes in cultural attitudes and consumer tastes, have created a condition for the proliferation of controversial ads recognised by many if not all consumers as manipulative, deceptive, exploitative, and/or culturally insensitive. Controversial ads sometimes involve global brands as well, when the latter fail to show sensitivity to Chinese people's feelings. Here nationalist sentiments clearly play a role in fuelling emotional responses to ads regarded as humiliating to Chinese culture. Differences in the country of origin matter: Japanese ads suffer from a greater risk of causing controversy than American ads, because of Japanese militarism in the past and its resurfacing in recent years. Interestingly, controversies are globalised thanks to communication technologies that transcend national boundaries. Hence a Chinese ad featuring a lookalike of the late Princess Diana triggered outrage in Britain, and a Citroen in Spain ad playing with the image of Mao Zedong caused an uproar among Chinese, leading to the withdrawal of the advertisement.

7 The final chapter addresses the implications of the digital revolution for Chinese advertising by zooming in on three dominant advertising practices: China Central Television's annual auction of its most coveted advertising slots, Unilever's collaboration with Chinese media to produce branded entertainment, and participatory marketing of a popular Chinese smartphone brand, Xiaomi. CCTV's advertising practice is included here as a legacy of the broadcasting era, whereas the latter two, by incorporating online media and fandom, represent emerging trends such as the fusion of advertising and content, convergence of different media platforms, and participatory marketing centred on fan activities. For readers interested in product placement (or its higher form of branded entertainment), or commodification of audiences' or users' physical, intellectual, and emotional labour in the making of digital media products, the case studies of Unilever and Xiaomi provide valuable information on how these global trends are manifested and perhaps even spearheaded in China. In particular, the section on how Unilever's hair product, Clear, was successfully 
integrated into the setting, plot, and character development of a youth-oriented television drama series, Unbeatable, is full of great insights on the influence of product placement on content development. This chapter is an important update on Chinese advertising in the digital era.

As lucidly illustrated by Li's book, advertising in China has been shaped by state policies and regulations, marketisation and privatisation of the economy, cultural transformation, digital media and communication technologies, and glocalising activities of multinational corporations in the Chinese market. It epitomises China's dual desire to search for an alternative modernity and emulate Western practices of capitalism, the tension of which results in some of the unique features of Chinese advertising. Yet Li also observe that ironically, as "pervasive developmentalism and neoliberalism narrow the differences between Chinese and foreign ad practices" ( $p$. 230), such tension might be partially resolved. Li does an admirable job weaving insights from critical cultural theories into rich empirical analyses. Occasionally Li seems to be directly addressing advertising practitioners when offering suggestions such as "Using global advertising agencies can be a good idea in this case" (p. 197), or "Advertisers selling to highly educated globally minded consumers, as well as to rural residents, should be more cautious when using sex-based strategies" (p. 181). But overall Li successfully maintains a balance between theory-based critique and practicebased knowledge. She is at once sympathetic to the dilemmas of Chinese advertising firms and attentive to the new forms of domination and exploitation in Chinese advertising, and to the ways in which Chinese and Western practices converge as China integrates itself into global capitalism.

On a final and separate note, Chapters 2 and 6 include brief but informative discussions of advertising in the first decade of the market reform era. They are reminders that a very rich cultural history of advertising remains to be written by delving into the debates, controversies, and uncertainties surrounding this new business and cultural form. A study of the emergence of consumerism from a socialist country, and the making of the consumer out of the socialist subject, will be of great interest to China historians and Chinese media scholars.

\section{AUTHOR}

\section{RUOYUN BAI}

Ruoyun Bai is Associate Professor of Media Studies at the Department of Arts, Culture, and Media (UTSC) of the University of Toronto (rbai@utsc.utoronto.ca). 